\title{
Effect of the Gravel Filters and Plastic Cover on Improving Water Infiltration Process and Increasing Moisture Storage of Rainwater Harvesting Systems in Sloping Lands
}

\section{Li Feng}

Guangdong University of Technology - University Town Campus: Guangdong University of Technology Jiajun Liu

Guangdong University of Technology - University Town Campus: Guangdong University of Technology Hazi Mohammad Azamathulla ( $\square$ azmatheditor@gmail.com )

University of the West Indies at Saint Augustine https://orcid.org/0000-0002-5436-4147

Mohammad Mehdizadeh Youshanlouei

Ton Duc Thang University

\section{Research Article}

Keywords: Rainwater harvesting, Gravel filter, Plastic cover, Piedmont plain

Posted Date: November 22nd, 2021

DOI: https://doi.org/10.21203/rs.3.rs-1093093/v1

License: (1) This work is licensed under a Creative Commons Attribution 4.0 International License. Read Full License 


\section{Abstract}

Rainwater harvesting is a suitable method to plant seedlings in sloping lands in arid and semi-arid regions. In this research, a combination of plastic coating and gravel filter has been used to penetrate water into the soil. In this method, water is stored in the soil during the rainy months and the plant uses these waters in the warm months of the year. For this purpose, five treatments (with three replications) including control treatment, system vegetation removal with filter, system vegetation removal without filter, semi-insulated system with filter and semi-insulated system without filter are considered. Two sensors are installed in each of the treatments at a depth of $20 \mathrm{~cm}$ and $60 \mathrm{~cm}$ of soil, which will record moisture in seven-day periods. Apricot seedlings have been planted in all treatments. The information obtained was analyzed through a completely randomized block design. The results showed that the semi-insulated treatment with gravel filter stored significant moisture in the soil rather than other treatments and stored more moisture in the warm months of the year. The results showed that semi-insulated treatment with gravel filter is a suitable solution to increase soil moisture in the warm months of the year (June, July, August and September).

\section{Introduction}

Establishment of rainwater catchment systems to collect sufficient rainwater from the catchment area and optimal use of low daily rainfall to facilitate vegetation can be a solution to deal with stress and permanent water shortage crisis, especially in arid and semi-arid regions (Kahinda and Taigbenu., 2011; Noori and Zare Chahouki., 2018; Yazar et al. 2014 ). Reservoir surface systems, in addition to their important role in the establishment and development of vegetation, control and store runoff on sloping surfaces, Reservoir surface systems penetration into the soil, increase moisture storage in soil profiles, and reduce evaporation from the soil surface in watersheds ( Shaxson and Barber., 2003). In the field of rainwater extraction methods, extensive research has been done or is being done in most parts of the world regarding the use of insulated and semi-insulated surfaces, the difference between which is in the type of exploited runoff (Goddosi et al., 2003). In this regard, we can refer to the methods of applying insulating coatings such as bitumen, paraffin, or plastic and other methods, such as collecting pebbles and vegetation from the surface, which is used according to the conditions of each region and research objectives (Critchley., 1991). Among the methods used in rainwater catchment systems to infiltrate runoff, the use of plant mulch, which in terms of high porosity and its use in water retention, plays an important role in absorbing moisture and providing suitable conditions for plant growth. At present, in connection with the storage of moisture in the soil profile, various methods are used, such as the use of animal and plant residues or the use of superabsorbents. For example, the use of three plant species of olive, pine and Atriplex showed that there was a significant difference in soil moisture between irrigation periods of 20,45 and 60 days. Therefore, superabsorbents have a great effect on soil moisture retention and growth of plant species (Pourmidani and Khoddaman., 2005). The soil profile can act as a water storage reservoir and this depends on factors such as depth, texture, soil structure, permeability and water holding capacity in the soil. Therefore, paying attention to all the aforementioned factors can play an important role in the establishment and continuity of water in the soil profile and help to establish fruitful trees (Lalljee and Facknath., 1999). Straw mulch can reduce the rate of evaporation from the soil surface, protect the surface from direct impact of raindrops, increase soil accumulation and increase biological activity (Blanco-Canqui and Lal., 2009; Chen et al., 2007). In addition to plant mulch, sandy mulch also allows runoff 
to penetrate deep into the soil. In this regard, the role of plant mulch in changing soil moisture and increasing crop production has been investigated. Its use in agriculture is not recommended due to its excessive complexity. This issue has made possible the use of sand filters in catchment surface systems due to easier implementation and availability of required materials and has played a significant role in faster runoff penetration and increase soil moisture (Gaderi., 2004). Li (2000) in her work on the use of pebble mulch in China, showed that the use of pebble mulch, while protecting the soil, has played an important role in extracting rainwater, reducing soil evaporation, and maintaining its fertility. For this purpose, this method is currently used in 118 thousand hectares of land in Guangzhou Province, China. In another study conducted by Yanni et al (2003) to investigate the distribution of water in the root zone of the plant as well as the potential for moisture storage in the soil, the results showed that the use of gravel mulch or gravel filter plays a significant role in increasing effective soil porosity. It had a soil depth of 25 to $50 \mathrm{~cm}$. In this regard, reviewing the results of research conducted by Abu-Awad (1998) shows that the use of sand filters at intervals of one, two, three, and four meters have a different effect on increasing soil moisture. Accordingly, treatments with distances of one, two, and three meters with 60,45 , and 35\% increase in moisture at a depth of $60 \mathrm{~cm}$ of the soil profile illustrates an important role in increasing moisture, compared to natural treatment. Therefore, in the present study, by applying sand filter treatment in the catchment surface system, its effect on increasing soil moisture compared to natural soil conditions has been investigated. Other field experiments confirm the role of sand mulch in improving soil conditions, plant growth rate, crop yield, and water use efficiency (Bu et al.,2013; Sun et al.,2012). For example, gravel mulch on the China Loess Plateau significantly increased the total weight of plant matter by $11-41 \%$ and grain yield by $17-70 \%$, respectively (Bu et al.,2013). The use of mulch is one of the most effective measures to improve water use efficiency and grain yield in arid areas (Gan et al.,2013). Plastic coatings are also widely accepted to change soil temperature and moisture and potentially improve crop production in arid agricultural areas (Wang et al.,2009; Fisher., 1995; Cook et al.,2006). Previous studies have shown that plastic cover can prevent evaporation of plant water due to evaporation (Li et al.,2013), improve soil temperature, affect crop production (Li et al.,2013) and increase soil permeability (Gan et al.,2013). Accordingly, plastic coating measures significantly increase crop growth and increase the efficiency of water resources (Liu et al.,2010). Mulching is also an effective way to reduce soil water evaporation, where water is available for crops, which improves wheat growth and development and increases crop production and water use efficiency (Li et al.,2016). At present, plastic coatings are widely used to increase soil temperature and reduce soil evaporation in the production of vegetables and agricultural products. It is becoming a good method for agriculture in arid, semi-arid, and semi-humid areas, especially when irrigation water is not available and spring temperatures are low (Dong et al., 2009). Mulching techniques are widely used for cereals, fruit trees, and vegetable crops, etc. (Li et al., 2000). Yi et al. (2010) in northwest China showed that plastic coating is an effective way to save water consumption. The use of this mulch reduced evapotranspiration, improved corn grain yield, and increased water productivity by $23-25 \%$. Wang et al. (2009) on the China Loss Plateau showed that the use of plastic cover can increase soil temperature at a depth of $10 \mathrm{~cm}$ to $2.3^{\circ} \mathrm{C}$ before July and close to $1.2^{\circ} \mathrm{C}$ after July. Its combination with basic fertilizer showed that corn grain yield increased by $10.61 \%, 9.48 \%$, and $15.36 \%$ during three consecutive years, respectively. Research by Lee et al. Li, C. S.et al. (2016) on the China Plateau also showed that mulch increases soil moisture in winter and spring. For example, the volume of soil moisture at a depth of 0-20 cm in the winter wheat field increased by $3.5 \%$, and in the range of $0-80 \mathrm{~cm}$ in the corn and potato fields increased by 4 to $6 \%$. These studies focused mainly on the effect of mulch on soil temperature, soil moisture, or crop 
yield for crops such as corn, potatoes, winter wheat, etc. (Xiukang et al.,2015). Lee et al. (2000) examined and compared several rainwater harvesting methods in China and showed that despite the huge difference in runoff coefficient, the plastic cover can produce more runoff than the bare soil method even in low intensity rainfall. This study recommends the use of pebble mulch and plastic coating methods to extract rainwater. Banyasadi et al. (2020) investigated the effect of semi-insulated and natural surfaces on soil moisture changes in catchment surface systems in Kerman province. Soil moisture was measured at three depths of 25,50 , and $75 \mathrm{~cm}$ of seedling holes. The results of comparing the mean percentage of soil moisture in different treatments showed that at depths of 50 and $75 \mathrm{~cm}$ of seedling pits, there was a significant difference between different treatments at a probability level of $5 \%$. Banyasadi et al. (2020) recommended the use of rainwater catchment systems, especially semi-insulated systems, along with the use of gravel filters to increase the moisture storage of soil profiles in the area of root development of fruit trees in orchards. These cases, along with other research conducted in this field, which mainly examines the use of different materials with the aim of increasing the moisture storage capacity of soil profiles, can be used as an option in waterlevel systems. What is certain is that popular acceptance and watershed culture will have an important impact on the choice of methods. The research results of ( Shaxson and Barber., 2003) show that the focus of activities is mainly to study the specific behavior of each of the five factors (including rainwater extraction, infiltration of runoff collected in the soil, the concept of flow component in sloping surfaces, moisture storage in profiles, soil and reduced evaporation from the soil surface). Therefore, it is necessary to provide methods that take into account the combined findings and examine the results obtained from them. These methods should have practical aspects and its implementation, while reducing the loss of water and soil resources and creating the right conditions for achieving development goals, should play a decisive role in improving the standard of living. For this reason, one of the differences between the present study and other methods is in the use of a combination of different operations. In order to increase the moisture storage of soil profiles and provide suitable substrates for the construction of sloping gardens. Therefore, the purpose of this study is to introduce the combined role of gravel filters with plastic coating in increasing the efficiency of catchment surface systems for the establishment and development of effective vegetation, which was done by combining the results of research conducted in this field.

\section{Materials And Methods}

\subsection{Study area:}

Khorramabad Research Station (with an area of 8.5 hectares) in $28 \mathrm{~km}$ south of Urmia city (Baranduz region) in the geographical coordinates of 45 degrees and 3 minutes and 30 seconds to 45 degrees and 4 minutes and 5 seconds east longitude and 37 degrees and 25 minutes and 10 seconds to 37 degrees and 25 minutes and 45 seconds north latitude. According to the climatic classification, Gaussian has a cold steppe climate and its humidity and heat regime are Xeric and Mesic, respectively. The series of soils in this station is classified in the category of Inceptisols. Figure 1 shows the location of the area in Google Earth and a schematic of the plots created at this station. Figure 2 also shows an example of semi-insulated plots with plastic and sand cover and a schematic of the catchment surface system.

Dimensions design of water level systems: 
The dimensions of water intake systems are one of the important parameters in meeting the water needs of the plant planted in them. Therefore, plant water requirement is one of the determining factors of system level. In the present study, the dimensions of water intake systems were calculated based on the factors of plant water requirement, annual rainfall, root area, runoff coefficient, and efficiency factor after selecting the type of system, using (Equation 1) [9,7].

$$
\mathrm{MC}=\mathrm{RA} \times \frac{\mathrm{WR}-\mathrm{DR}}{\mathrm{DR} \times \mathrm{K} \times \mathrm{EFF}}
$$

Where, $\mathrm{MC}=$ catchment area per square meter, $\mathrm{RA}=$ average root growth of the plant used per square meter, $W R=$ water requirement of the plant per millimeter per year, $D R=$ amount of annual precipitation per millimeter, $\mathrm{K}$ = runoff coefficient per percent, EFF = coefficient Runoff efficiency as a percentage.

The catchment area in the Khorramabad station area of Urmia is equal to 30 square meters and the average annual rainfall in the area is about $320 \mathrm{~mm}$ (Dizaj station). In this study, a four-year-old apricot tree has been considered as a reference plant for estimating water requirement and its net irrigation requirement has been calculated based on the Penman-Monteith method in the Krapowat program equal to $610 \mathrm{~mm}$. The runoff coefficient for the insulation level is 0.6 and for the natural surface is 0.2 and the average of these two numbers is equal to $0.4[9,7]$. Other parameters used in calculating the area of catchment surface systems are presented in (Table 1).

\subsection{Construction of rainwater catchment systems:}

Experimental plots with five treatments and three replications are placed on a slope (Figure 2) with an area of 30 square meters in a completely randomized block design. The average slope of the plots is 12 to $15 \%$ in the southern direction. Water level treatments include natural surface plots (control treatment), system with gravel filter and vegetation removal, system without pebble filter and vegetation removal, semi-insulated system (with plastic cover) with gravel filter, and semi-insulated system (with plastic cover) without filter. In (Figure 1) the arrangement of treatments and iterations of plots of rainwater catchment surfaces is presented.

In natural treatment, the surface of the plots remains intact. In the semi-insulated treatment, all vegetation of the plot was removed and part of it was covered with plastic and pea sand. Figure 2 (left) shows a schematic of semi-insulated plots with plastic and sand cover, of which $5 \mathrm{~m}$ wide, $2.5 \mathrm{~m}$ wide is covered with plastic and sand, and the remaining $2.5 \mathrm{~m}$ (1.25 $\mathrm{m}$ on both sides)is uncovered. Therefore, the share of each insulated and non-insulated surface is equal in terms of area.

The soil series of the study area is from the large group of Calcixerepts. In this series of soils, the average percentage of clay is between 35 to $60 \%$ and its thermal regime is Mesic. In the studied lands, there is no limitation of salinity and alkalinity and the soil depth is very deep and the permeability of the soils is low.

\subsection{Planting hole preparation:}

Holes were dug at the end of each system to plant seedlings. In order to prevent water leakage stored in the hole in the direction of slope and increase the shelf life of moisture storage in the soil profile, especially in the root part of the plant, in each of these holes, the wall inside the seedling hole was insulated with plastic cover 
(dimensions $0.8 \mathrm{~m}^{2}$ ) and moisture absorbing material was added to the bottom of the hole to a height of 5 $\mathrm{cm}$. Twenty percente of the soil of the hole was also mixed with rotten organic matter.

\subsection{Create a gravel filter:}

Pebble filter with a diameter of about $10 \mathrm{~cm}$ and a depth of about $60 \mathrm{~cm}$ in the bottom of the seedling hole (at two points adjacent to the seedling) in order to rapidly penetrate the runoff and distribute it in the root zone, as well as supplementary irrigation (Figure 2, left ).

\subsection{Installation of soil moisture measuring sensors:}

In order to measure the volumetric moisture of the soil and compare its changes in each of the treatments, two sensors were installed as vertical bars at depths of 20 and $60 \mathrm{~cm}$ in each of the holes. The sensors were installed in the five treatments in the apricot pits.

\subsection{Measuring soil moisture:}

Changes in volumetric moisture content due to rainwater harvesting in each of the treatments at depths of 20 and $60 \mathrm{~cm}$ were measured by a TDR(Time Domain Reflectometry) device by connecting to vertical burial sensors one day after each rainfall.

\section{7. data analysis:}

The amount of volumetric soil moisture in the plots was measured at two depths of 20 and $60 \mathrm{~cm}$ for two years at 7-day intervals (in spring and summer) with a TDR hygrometer. In addition, soil moisture data at the site of the plots were measured 24 hours after each rainfall event (more than $5 \mathrm{~mm}$ ). Data were analyzed in SPSS software using a completely randomized block statistical method with five treatments and each treatment in three replications using Duncan's multi-domain method with a $95 \%$ confidence interval. To measure precipitation, a regular rain gauge of the Khorramabad meteorological station was used.

Table 1

Parameters used in calculating the area of surface water harvesting systems

\begin{tabular}{|llllll|}
\hline $\begin{array}{l}\text { Basin } \\
\text { area } \\
\left(\mathbf{m}^{2}\right)\end{array}$ & $\begin{array}{l}\text { Performance } \\
\text { factor }(\%)\end{array}$ & $\begin{array}{l}\text { Runoff } \\
\text { coefficient } \\
(\%)\end{array}$ & $\begin{array}{l}\text { Design amount } \\
\text { of rainfall(mm) }\end{array}$ & $\begin{array}{l}\text { Plant Water } \\
\text { requirements } \\
\text { (mm/year) }\end{array}$ & $\begin{array}{l}\text { Average root } \\
\text { expansion of the } \\
\text { plant }\left(\mathbf{m}^{2}\right)\end{array}$ \\
\hline 30 & 50 & 40 & 320 & 610 & 7 \\
\hline
\end{tabular}


Table 2

Data details (mean, standard deviation, and mean error)

\begin{tabular}{|c|c|c|c|c|}
\hline Depth (cm) & Treatment & Number & Average & SD \\
\hline \multirow[t]{6}{*}{$0-20$} & Control & 3 & 14.83 & 0.88 \\
\hline & Vegetation removal with filter & 3 & 17.04 & 0.85 \\
\hline & Vegetation removal without filter & 3 & 14.84 & 2.54 \\
\hline & Semi-insulated with filter & 3 & 18.83 & 6.35 \\
\hline & Semi-insulated without filter & 3 & 19.58 & 6.18 \\
\hline & Total & 15 & 17.01 & 1.66 \\
\hline \multirow[t]{6}{*}{$20-60$} & Control & 3 & 14.05 & 0.77 \\
\hline & Vegetation removal with filter & 3 & 15.58 & 0.73 \\
\hline & Vegetation removal without filter & 3 & 18.02 & 1.16 \\
\hline & Semi-insulated with filter & 3 & 17.86 & 1.10 \\
\hline & Semi-insulated without filter & 3 & 21.85 & 3.24 \\
\hline & Total & 15 & 17.47 & 0.78 \\
\hline
\end{tabular}

Table 3

Analysis of variance and significance level between treatments

\begin{tabular}{|c|c|c|c|c|c|c|}
\hline $\begin{array}{l}\text { (cm) } \\
\text { Depth of } \\
\text { sensor }\end{array}$ & $\begin{array}{l}\text { Sources of } \\
\text { changes }\end{array}$ & $\begin{array}{l}\text { Sum of } \\
\text { squares }\end{array}$ & $\begin{array}{l}\text { Degrees of } \\
\text { freedom }\end{array}$ & $\begin{array}{l}\text { Average of } \\
\text { squares }\end{array}$ & $F$ & Sig. \\
\hline \multirow[t]{3}{*}{$0-20$} & $\begin{array}{l}\text { (Between } \\
\text { groups) }\end{array}$ & 57.59 & 4 & 14.45 & \multirow[t]{3}{*}{0.279} & \multirow[t]{3}{*}{0.885} \\
\hline & (Within groups) & 518.52 & 10 & 51.85 & & \\
\hline & (Total) & 576.32 & 14 & & & \\
\hline \multirow[t]{3}{*}{$20-60$} & $\begin{array}{l}\text { (Between } \\
\text { groups) }\end{array}$ & 43.81 & 4 & 10.95 & \multirow[t]{3}{*}{1.284} & \multirow[t]{3}{*}{0.339} \\
\hline & (Within groups) & 85.29 & 10 & 8.52 & & \\
\hline & (Total) & 129.10 & 14 & & & \\
\hline
\end{tabular}

\section{Results}


The results of the mean of soil moisture data at two depths of 20 and $60 \mathrm{~cm}$ show that the level of significance is greater than 0.05 and there is no significant difference between treatments. Therefore, both depths are in the same group (Tables 2 and 3 ). The results of comparing the mean volumetric soil moisture of the treatments at a depth of $20 \mathrm{~cm}$ showed that the semi-insulated surface treatment with gravel filter had the highest moisture content (with an average of 19.58) and the control treatment had the lowest moisture content (with an average of 14.83). Also, the comparison of the average volumetric soil moisture at a depth of $60 \mathrm{~cm}$ showed that the semi-insulated treatment with gravel filter with an average of 21.84 had the highest moisture content and the control treatment with an average of 14.05 had the lowest moisture (Table 2).

\subsection{Comparison of soil moisture in sampling holes at a depth of $20 \mathrm{~cm}$ :}

The average percentage of volumetric soil moisture at a depth of $20 \mathrm{~cm}$ of soil between the two treatments of removal of unfiltered cover and removal of cover with filter is 14.77 and 17.14, respectively. Table 4 shows the T-test comparing the mean of the two treatments. Due to the significance of the value of $F$, heterogeneous variance row information is used, which indicates a significant difference at the level of one percent between the means of treatments. In other words, the amount of soil moisture in the filter removal system with filter is significantly higher than the system without filter. The average percentage of volumetric soil moisture at a depth of $20 \mathrm{~cm}$ between the two treatments of semi-insulated surface without filter and semi-insulated surface with filter is 19.20 and 19.57, respectively. Table 5 shows the results of analysis of variance between the semi-insulated and semi-insulated treatments with a filter at a depth of $20 \mathrm{~cm}$ in the soil, which shows that the value of $\mathrm{F}$ is not significant, so the first row data is used. The results of the $T$ test indicate that there is no significance in the sense that the mean of the data is equal. According to the results of analysis of variance (Tables 4 and 5, Figure 3 ) at a depth of $20 \mathrm{~cm}$, it can be inferred that the semi-insulated treatment with gravel filter with an average humidity of 19.58 has a significantly higher humidity compared to the control treatment and cover removal treatment has witha filter. Semi-insulated treatment without filter with an average moisture content of 18.82 is in second place in terms of soil moisture. Non-filter treatment with vegetation removal and semi-insulated treatment without pebble filter with averages of 17.03 and 18.82, respectively, are similar in terms of soil moisture content and have less moisture than semi-insulated treatment with pebble filter. The control treatment with an average of 14.83 has the lowest moisture content.

Table 4. Analysis of variance of two spray-removal and filter-removal treatments at $20 \mathrm{~cm}$ depth of soil 
soil Levens Test t-test for Equality of Means

moisture

Mean

Difference

F Sig. df

df

95\% Confidence Interval of the

$\mathrm{t}$

Difference
Sig.(2- Mean Std. Error tailed)

Difference Difference

\begin{tabular}{llllllllll} 
& & & & & & & (Lower) & (Upper) \\
$\begin{array}{l}\text { Equal } \\
\text { variances } \\
\text { assumed }\end{array}$ & 8.92 & 0.003 & -3.72 & 280 & 0 & -2.25 & 0.60 & -3.44 & -1.06 \\
\hline $\begin{array}{l}\text { Non-Equal } \\
\text { variances } \\
\text { assumed }\end{array}$ & & & -3.72 & 267.16 & 0 & -2.25 & 0.60 & -3.44 & -1.06 \\
\hline
\end{tabular}

Table 5. Analysis of variance of two semi-insulated and semi-insulated treatments with filter at $20 \mathrm{~cm}$ soil depth

\begin{tabular}{|c|c|c|c|c|c|c|c|c|c|}
\hline \multirow{3}{*}{$\begin{array}{l}\text { soil } \\
\text { moisture } \\
\text { Mean } \\
\text { Difference }\end{array}$} & \multicolumn{2}{|c|}{$\begin{array}{l}\text { Levens } \\
\text { Test }\end{array}$} & \multicolumn{7}{|c|}{ t-test for Equality of Means } \\
\hline & \multirow[t]{3}{*}{$\mathrm{F}$} & \multirow[t]{3}{*}{ Sig. } & \multirow[t]{3}{*}{$\mathrm{t}$} & \multirow[t]{3}{*}{$\mathrm{df}$} & \multirow[t]{2}{*}{$\begin{array}{l}\text { Sig.(2- } \\
\text { tailed) }\end{array}$} & \multirow{3}{*}{$\begin{array}{l}\text { Mean } \\
\text { Difference }\end{array}$} & \multirow{2}{*}{$\begin{array}{l}\text { Std. Error } \\
\text { Difference }\end{array}$} & \multirow{2}{*}{\multicolumn{2}{|c|}{$\begin{array}{l}95 \% \text { Confidence } \\
\text { Interval of the } \\
\text { Difference }\end{array}$}} \\
\hline & & & & & & & & & \\
\hline & & & & & & & & (Lower) & (Upper) \\
\hline $\begin{array}{l}\text { Equal } \\
\text { variances } \\
\text { assumed }\end{array}$ & 0.29 & 0.86 & -0.6 & 280 & 0.51 & -0.36 & 0.55 & -1.45 & 0.72 \\
\hline $\begin{array}{l}\text { Non-Equal } \\
\text { variances } \\
\text { assumed }\end{array}$ & & & -0.6 & 279.64 & 0.51 & -0.36 & 0.55 & -1.45 & 0.72 \\
\hline
\end{tabular}

Table 6. Analysis of variance of two spray-removal and filter-removal treatments at $60 \mathrm{~cm}$ depth of soil 

Soil Levens t-test for Equality of Means
moisture Test

Mean

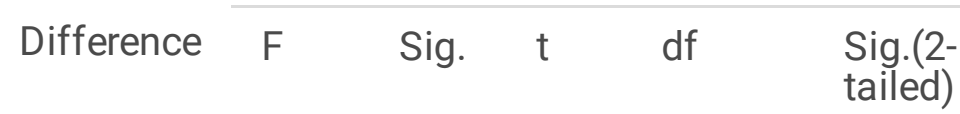

95\% Confidence

Interval of the

Mean Std. Error Difference

Difference Difference

\begin{tabular}{lccccccccc} 
& & & & & & & & (Lower) & (Upper) \\
$\begin{array}{l}\text { Equal } \\
\text { variances } \\
\text { assumed }\end{array}$ & 3.09 & 0.08 & -4.5 & 280 & 0 & -2.44 & 0.54 & -3.51 & -1.37 \\
$\begin{array}{l}\text { Non-Equal } \\
\text { variances } \\
\text { assumed }\end{array}$ & & -4.5 & 276.23 & 0 & -2.44 & 0.54 & -3.51 & -1.37 \\
\hline
\end{tabular}

\subsection{Comparison of soil moisture in sampling holes at a depth of $60 \mathrm{~cm}$ :}

The average percentage of volumetric soil moisture at a depth of $60 \mathrm{~cm}$ between the two treatments of cover removal and cover removal with filter are 15.56 and 18.01, respectively. Due to the significance of the $F$ test, the information in the first row of Table 6 has been used. There is a significant difference between the means of the treatments. The average percentage of volumetric soil moisture at a depth of $60 \mathrm{~cm}$ between the two treatments of semi-insulated surface without filter and semi-insulated surface with filter are 17.82 and 21.95, respectively. Table 7 shows the variance status, the value of the F-statistic for the Loon test for homogeneity of variances of the two treatments. Since $F$ is significant, heterogeneous variance row information is used as well as the T-value of degree of freedom of test probability. There is a significant difference at the level of one percent between the means of treatments. According to the results of analysis of variance (Tables 6 and 7 , Figure 3) at a depth of $60 \mathrm{~cm}$, it can be inferred that the semi-insulated treatment with gravel filter with average moisture of 21.84 and the coating removal treatment with gravel filter with an average of 18.01 are similar. They have the highest moisture content among the studied treatments. Removal treatment, unfiltered cover, and semi-insulated treatment without filter with similar averages of 15.58 and 17.86 , respectively, were similar in terms of soil moisture content, which have significantly less moisture than filter removal treatments and semi-insulated filters. The control hole with an average of 14.04 has the lowest moisture content. The results of research in Tabriz by Yarahmadi et al. (2016) showed that the moisture content of semi-insulated treatment with gravel filter at a depth of $20 \mathrm{~cm}$ (with an average of 35.94) and a depth of $60 \mathrm{~cm}$ (with an average of 30.56) is significantly higher than other treatments, which agrees with the results of the present study. In the present study, the effect of gravel filters on increasing soil moisture storage is also evident. The results of this study showed that the effect of gravel filter is more than the effect of semi-insulated surface so 
that in the coating removal and semi-insulated systems that use gravel filter, the amount of moisture is higher than systems without gravel filter.

Table 7. Analysis of variance of two semi-insulated and semi-insulated treatments with filter $60 \mathrm{~cm}$ depth of

\begin{tabular}{|c|c|c|c|c|c|c|c|c|c|}
\hline \multirow{5}{*}{$\begin{array}{l}\text { soil } \\
\text { moisture } \\
\text { Mean } \\
\text { Difference }\end{array}$} & \multicolumn{2}{|c|}{ Levens Test } & \multicolumn{7}{|c|}{ t-test for Equality of Means } \\
\hline & \multirow{5}{*}{$\mathrm{F}$} & & & & & & & & \\
\hline & & \multirow[t]{4}{*}{ Sig. } & \multirow[t]{4}{*}{$\mathrm{t}$} & \multirow[t]{4}{*}{$d f$} & \multirow[t]{4}{*}{$\begin{array}{l}\text { Sig.(2- } \\
\text { tailed) }\end{array}$} & & & \multirow{3}{*}{\multicolumn{2}{|c|}{$\begin{array}{l}95 \% \text { Confidence } \\
\text { Interval of the } \\
\text { Difference }\end{array}$}} \\
\hline & & & & & & Mean & Std. Error & & \\
\hline & & & & & & Difference & Difference & & \\
\hline & & & & & & & & (Lower) & (Upper) \\
\hline $\begin{array}{l}\text { Equal } \\
\text { variances } \\
\text { assumed }\end{array}$ & 16.12 & 0 & -7.3 & 280 & 0 & -4.13 & 0.56 & -5.24 & -3.02 \\
\hline $\begin{array}{l}\text { Non-Equal } \\
\text { variances } \\
\text { assumed }\end{array}$ & & & -4.51 & 252.90 & 0 & -4.13 & 0.56 & -5.24 & -3.02 \\
\hline
\end{tabular}

\section{Summary}

The results of this study showed that there is a significant difference between the mean volume of soil moisture at a depth of $20 \mathrm{~cm}$ and $60 \mathrm{~cm}$ for different treatments. At a depth of $20 \mathrm{~cm}$, the semi-insulated treatment with gravel filter (with an average of 19.58) and the control treatment (with an average of 14.81) had the highest and lowest volumetric soil moisture, respectively. Semi-insulated treatments without filter, removal of coating without filter, and removal of coating with filter were in the next ranks, respectively. At 60 $\mathrm{cm}$ soil depth, semi-insulated treatment with gravel filter (with an average of 21.84) and control treatment (with an average of 14.02) had the highest and lowest volumetric soil moisture, respectively. Filter removal treatments, unfiltered semi-insulation, and unfiltered coating removal treatments were in the next ranks, respectively. At a soil depth of 0-20 cm, the average moisture content over a two-year period was higher than the other treatments in semi-insulated surfaces without gravel filter and semi-insulated with filter, while the control treatment had the lowest moisture content. The two-year average moisture content of soil profiles at a depth of $20-60 \mathrm{~cm}$ in semi-insulated treatment with gravel filter was $25 \%$ higher than other treatments. Also, the use of a gravel filter at a depth of $20-60 \mathrm{~cm}$ stores $14 \%$ more moisture than the depth of $0-20 \mathrm{~cm}$ of soil, while in other treatments the amount of moisture storage at a depth of $20-60 \mathrm{~cm}$ is generally less than a depth of $0-20 \mathrm{~cm}$.

\section{Discussion}


According to the results of this study, semi-insulated treatment with gravel filter had the highest soil moisture storage at a depth of $60 \mathrm{~cm}$, which is suitable for storing soil moisture within dry months of the growing season of the year (June, July, August, and September). Therefore, the results of this study indicate that the use of gravel filter leads to the collected runoff to the soil profile and increases the moisture reserve, which can increase the safety factor and the survival of orchards on sloping lands.

The findings of this study showed that the effect of gravel filter is more than the effect of semi-insulated surface. In systems that use pebble filter, the amount of moisture is higher than other systems. The presence of semi-insulated surface alone does not significantly increase the soil moisture content, because there is no significant difference in filter removal systems without filter and semi-insulated without filter, which differ only in the presence of semi-insulated surface. However, the presence of semi-insulated surface with gravel filter caused a significant difference in soil moisture. This means that the combined use of the semi-insulated surface and the gravel filter has a greater effect than the use of the filter alone. This was evident in filter removal and semi-insulated filter systems. Previous studies have also confirmed the effect of gravel filters on increasing moisture retention and storage in soil profiles (Roughani,, 2007; Gaderi, 2004; Baniasadi et al. 2020). Also, a study in Urmia by Khajei and Bernus (2005) used plastic cover and gravel protection with a thickness of $5 \mathrm{~cm}$ at the surface of the pit and a gravel filter at a depth of $50 \mathrm{~cm}$ inside the runoff collecting hole. Significant moisture was found to be retained in the soil and the amount of moisture in the least rainy year and the driest month in this treatment was $52.16 \%$ higher than the control treatment. Yadollahi et al. (2012) reported that the system of rainwater catchment surfaces with gravel filter significantly increases seedling tree growth compared to the control treatment Sadeghzadeh et al.(2014). While investigating the effect of gravel filter treatment with earthenware and perlite on increasing soil moisture retention, pistachio seedling pits also showed that gravel filter treatment at a significant level of one percent increases the volumetric moisture content of the compared with other treatments. The results of Banyasadi et al.(2020) in Kerman province also showed that the best option to increase soil moisture in the area of tree root development is to use a water intake system, part of which is insulated, along with the use of gravel filter. Also, studies conducted abroad have expressed the need to use semi-insulated surfaces to increase the runoff coefficient and store it in rainy times as one of the important measures to provide water resources in arid areas (Qadir et al.2007; Hatibu et al. 2000). Therefore, it can be acknowledged that the use of gravel filter can significantly increase soil moisture at the surface of the seedling pit and prevent water loss due to evaporation. Also, due to the direct transfer of the extracted water to the root zone of the plant, it retained the moisture in the root zone of the plant for a longer period. The result will be an important part of the plant's water supply in times of crisis. This issue is of special importance in arid and semi-arid regions where the temporal distribution of rainfall is not suitable and most of the rainfall occurs in winter or in the first few months of the year and in other seasons the plants face water stress. Therefore, the extraction of rainwater using semi-insulated surfaces and gravel filters causes the direct transfer of water to the root zone of the plant and is a suitable response to deal with this problem. Supplying the water required by the plant and applying less irrigation and consequently, the possibility of increasing crop yield per unit area will improve the living conditions and increase the income of farmers and gardeners.

\section{Declarations}


Compliance with ethical standards

Conflicts of interest - No potential conflict of interest was reported by the authors.

Availability of data and material: - The datasets generated during and/or analyzed during the current study is available from the corresponding author on reasonable request

Code availability - Not applicable=

Authors' contributions: - Li Feng Data analysis, Jiajun Liu Conception or design of the work, Azamathulla Data collection Data analysis and interpretation, drafting the article done by Mohammad Mehdiadeh

Ethics approval: - Not applicable

Funding : Not applicable

Consent to participate: - Not applicable

Consent for publication: - Not applicable

\section{References}

1. Abu-Awwad, A. M. 1998. Influence of vertical sand column and supplemental irrigation on barley yield in arid soils affected by surface crust. Irrigation Science. 18(2):101-107.

2. Baniasadi, M., Seyed Alikhani, N. and Naghavi, H. 2020. Investigation of impact of semi-isolated and natural surfaces in moisture variations of optimized microcatchment systems. Journal of Irrigation and Water Engineering. 10(2): 89-103. (In Persian)

3. Blanco-Canqui, H. and Lal, R. 2009. Corn stover removal for expanded uses reduces soil fertility and structural stability. Soil Science Society of America Journal. 73(2): 418-426.

4. Bu, L. D., Liu, J. L., Zhu, L., Luo, S. S., Chen, X. P., Li, S. Q., ... and Zhao, Y. 2013. The effects of mulching on maize growth, yield and water use in a semi-arid region. Agricultural Water Management. 123, 71-78.

5. Chen, S. Y., Zhang, X. Y., Pei, D., Sun, H. Y. and Chen, S. L. 2007. Effects of straw mulching on soil temperature, evaporation and yield of winter wheat: field experiments on the North China Plain. Annals of Applied Biology, 150(3), 261-268.

6. Cook, H. F. Valdes, G. S. and Lee, H. C. 2006. Mulch effects on rainfall interception, soil physical characteristics and temperature under Zea mays L. Soil and tillage research. 91(1-2): 227-235.

7. Critchley, W. 1991. A manual for the design and construction of water harvesting scheme for plant production. FAO. AGL/MISC/17/91. Available from< http://www. fao. org/dowep/u3160e/4316e04. htm.

8. Dong, H. Li, W. Tang, W. and Zhang, D. 2009. Early plastic mulching increases stand establishment and lint yield of cotton in saline fields. Field Crops Research. 111(3): 269-275.

9. Farshi, A. A. 1998. Estimation of water Requirement for Major Crops in Iran (Volume2). Tehran. Soil and Water Research Institute. Agricultural Education affiliated with the Office of Educational Technology Services of the Ministry of Agriculture Jihad. 338 p. (In Persian) 
10. Fisher, P. D. 1995. An alternative plastic mulching system for improved water management in dryland maize production. Agricultural Water Management. 27(2): 155-166.

11. Gaderi, N. 2004. Basin-level optimization systems by increasing moisture retention in soil profiles in the Kurdstan Province. Soil Conservation and Watershed Management Research Institute. Research design report. 105 p. (In Persian)

12. Gan, Y. Siddique, K. H. Turner, N. C. Li, X. G. Niu, J. Y. Yang, C. ... and Chai, Q. 2013. Ridge-furrow mulching systems-an innovative technique for boosting crop productivity in semiarid rain-fed environments. In Advances in agronomy. 118: 429-476.

13. Goddosi, J., Shoaei, Z., Telvari, A., Mahdian M.H. and Gafori, A. 2003. Rainwater harvesting system project for environmental sustainable development. Scientific researches console of Iran (Agricultural Commission), Tehran, 707 p. (In Persian)

14. Hatibu, N. Mahoo, H. F. and Gowing, J. W. 2000. Rainwater harvesting for natural resources management: a planning guide for Tanzania. Technical Handbook, No. 22, RELMA, Nairobi, Kenya.

15. Kahinda, J.M. and Taigbenu, A.E. 2011. Rainwater harvesting in South Africa: Challenges and opportunities. Physics and Chemistry of the Earth, Parts A/B/C, 36(14-15), 968-976.

16. Khajae, E. and Bernose, E. 2005. A Survey of different treatments effect in increase moisture staying in soil profile in the rhombic micro catchments. Second National Conference on Watershed Management and Soil Management, Shahid Bahonar University. 780-886. (In Persian)

17. Lalljee, B. and Facknath, S. 1999. Water harvesting and alternate sources of water for agriculture. Prosi. 31(368): 48-54.

18. Li, C. S. Li, J. G. Tang, Y. L. Wu, X. L. Chun, W. U. Huang, G. And Hui, Z. E. N. G. 2016. Stand establishment, root development and yield of winter wheat as affected by tillage and straw mulch in the water deficit hilly region of southwestern China. Journal of integrative agriculture. 15(7): 1480-1489.

19. Li, R. Hou, X. Jia, Z. Han, Q. Ren, X. and Yang, B. 2013. Effects on soil temperature, moisture, and maize yield of cultivation with ridge and furrow mulching in the rainfed area of the Loess Plateau, China. Agricultural Water Management. 116: 101-109.

20. Li, S. X. Wang, Z. H. Li, S. Q. Gao, Y. J. and Tian, X. H. 2013. Effect of plastic sheet mulch, wheat straw mulch, and maize growth on water loss by evaporation in dryland areas of China. Agricultural water management. 116: 39-49.

21. Li, X. Y. 2000. Soil and water conservation in arid and semi-arid areas: the Chinese experience. Annals of Arid Zone. 39(4): 377-394.

22. Li, X. Y. Gong, J. D. and Wei, X. H. 2000. In-situ rainwater harvesting and gravel mulch combination for corn production in the dry semi-arid region of China. Journal of arid environments. 46(4): 371-382.

23. Liu, Y. Li, S. Chen, F. Yang, S. and Chen, X. 2010. Soil water dynamics and water use efficiency in spring maize (Zea mays L.) fields subjected to different water management practices on the Loess Plateau, China. Agricultural Water Management. 97(5): 769-775.

24. Noori, Z. and Zare Chahouki, M.A. 2018. Optimal use of rainwater harvesting: a strategy to deal with water shortages in arid and semi-arid regions. Journal of Water and Sustainable Development. 5(1): 115122. (In Persian) 
25. Pourmidani, A. S. and Khoddaman, H. 2005. Investigation of the effect of application of aquazorb polymer on irrigation of pine, olive and Atriplex seedlings. Forest and Poplar Research. 13: 92-79. (In Persian)

26. Qadir, M. Sharma, B. R, Bruggeman, A. Choukr-Allah, R. and Karajeh, F. 2007. Non-conventional water resources and opportunities for water augmentation to achieve food security in water scarce countries. Agricultural water management. 87(1): 2-22.

27. Roughani, M. 2005. Final Report of Basin Surface Systems Optimization Research Project. Institute for Soil Conservation and Watershed Management. Tehran. Iran, 122 p. (In Persian)

28. Roughani, M. 2007. Final Report of the National Project for the Optimization of Rainwater Composting Systems. Institute of Soil Conservation and Watershed Management, Tehran, Iran, 178 p. (In Persian)

29. Sadeghzadeh Reihan, M. Zarehaghghi, D. and Neyshabouri, M. 2014. Evaluation of Rainwater harvesting Methods in Increasing Soil Moisture and Pistachio Seedling Growth. Water and Soil Science. 23(4): 203214. (In Persian)

30. Shaxson, F. and Barber, R. 2003. Optimizing soil moisture for plant production: The significance of soil porosity. Soils Bulletin 79, Rome: Food and Agriculture Organization of the United Nations.

31. Sun, H. Shao, L. Liu, X. Miao, W. Chen, S. and Zhang, X. 2012. Determination of water consumption and the water-saving potential of three mulching methods in a jujube orchard. European Journal of Agronomy. 43: 87-95.

32. Wang, Y. Xie, Z. Malhi, S. S. Vera, C. L. Zhang, Y. and Wang, J. 2009. Effects of rainfall harvesting and mulching technologies on water use efficiency and crop yield in the semi-arid Loess Plateau, China. Agricultural water management. 96(3): 374-382.

33. Xiukang, W. Zhanbin, L. and Yingying, X. 2015. Effects of mulching and nitrogen on soil temperature, water content, nitrate-N content and maize yield in the Loess Plateau of China. Agricultural Water Management. 161: 53-64.

34. Yadollahi, A. Teymouri, N. Abdousi, V. and Sarikhani, S. 2012. Application of Superabsorbent in Microcatchments for Establishing Almond Orchards under Rainfed Condition. Journal of Water Research in Agriculture. 26(1): 93-104. (In Persian)

35. Yanni, S. Nimah, M. N. and Bashour, I. 2003. Gravel vertical mulching for improving water use efficiency of drip irrigated orchards. In IV International Symposium on Irrigation of Horticultural Crops 664 (pp. $673-$ 681).

36. Yarahmadi, J. Sadeghzadeh, M. E. Niknezhad, D. and Mehrvarzemoghanlou, K. 2016. Investigation of the gravel filters effect's in influence optimization and the increasing of Soil moisture storage in Rainwater catchment system levels. Watershed Management Researches Journal. 29(3): 2-13. (In Persia)

37. Yazar, A., Kuzucu, M., Celik, I., Sezen, S.M. and Jacobsen, S.E. 2014. Water harvesting for improved water productivity in dry environments of the Mediterranean region case study: Pistachio in Turkey. Journal of agronomy and crop science, 200(5), 361-370.

38. Yi, L. Shenjiao, Y. Shiqing, L. Xinping, C. and Fang, C. 2010. Growth and development of maize (Zea mays L.) in response to different field water management practices: Resource capture and use efficiency. Agricultural and Forest Meteorology. 150(4): 606-613. 
Figures

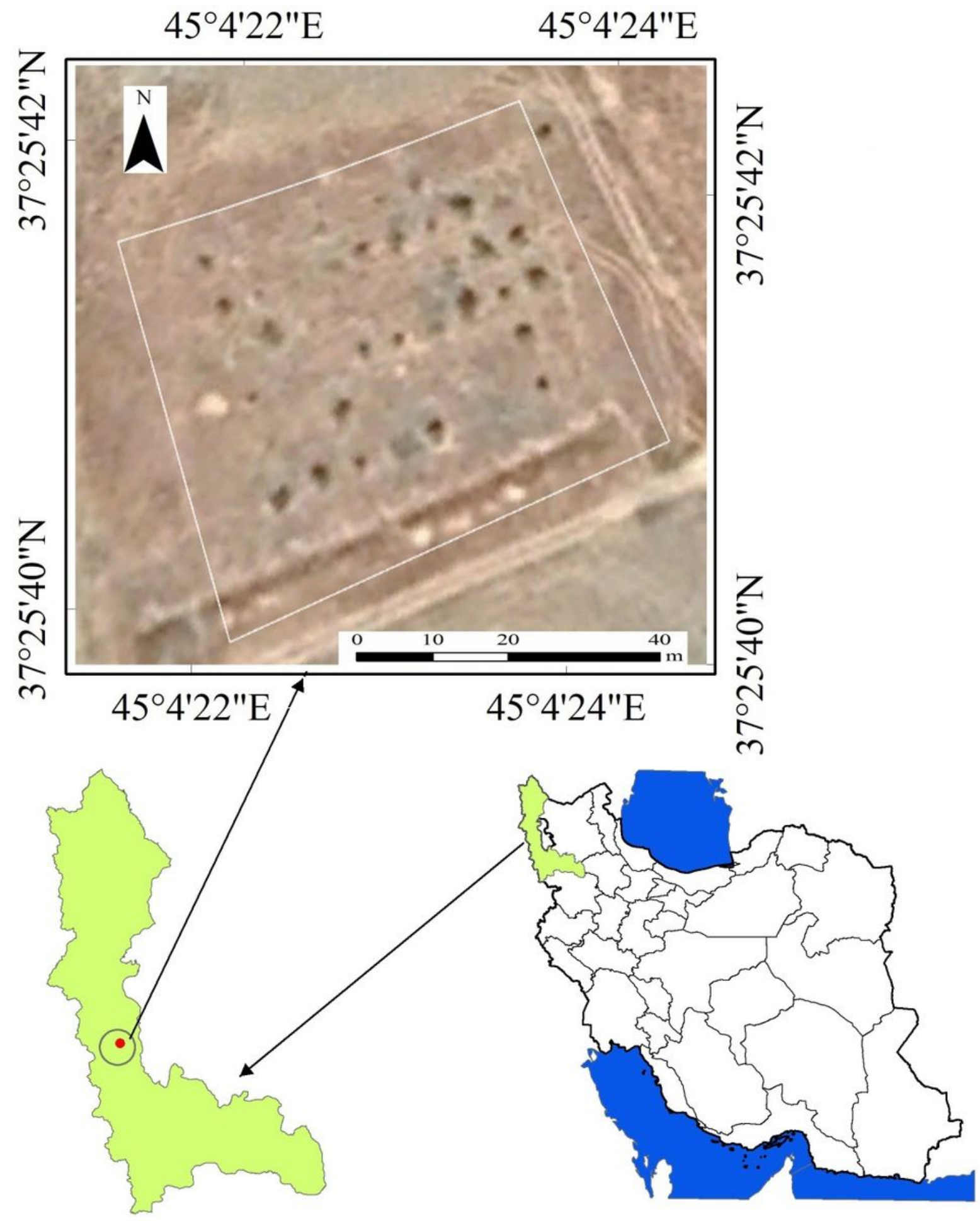

Figure 1

Location of research plots in Khorramabad station of Urmria 


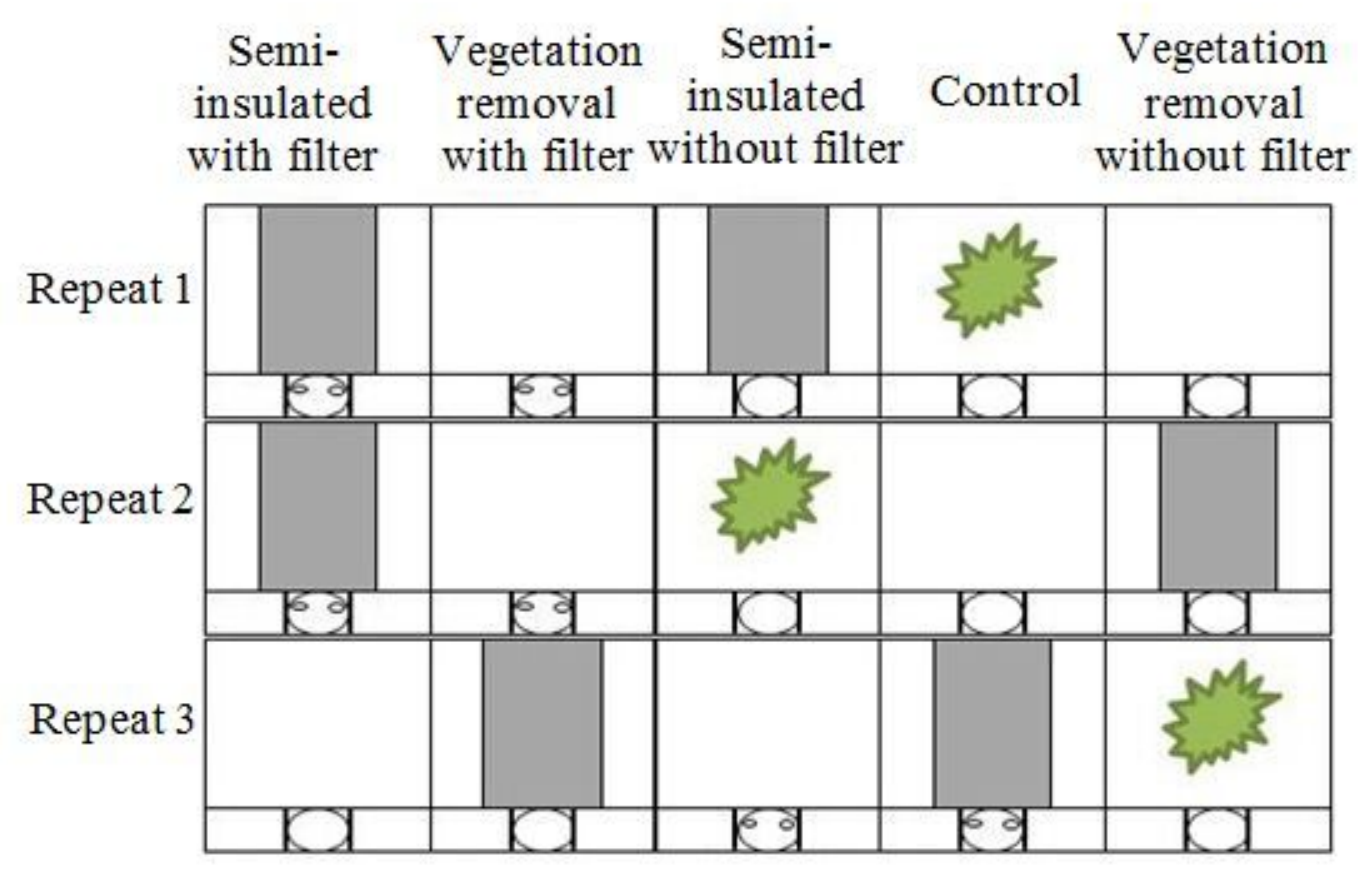

Figure 2

Plots schematic design

\section{Figure 3}




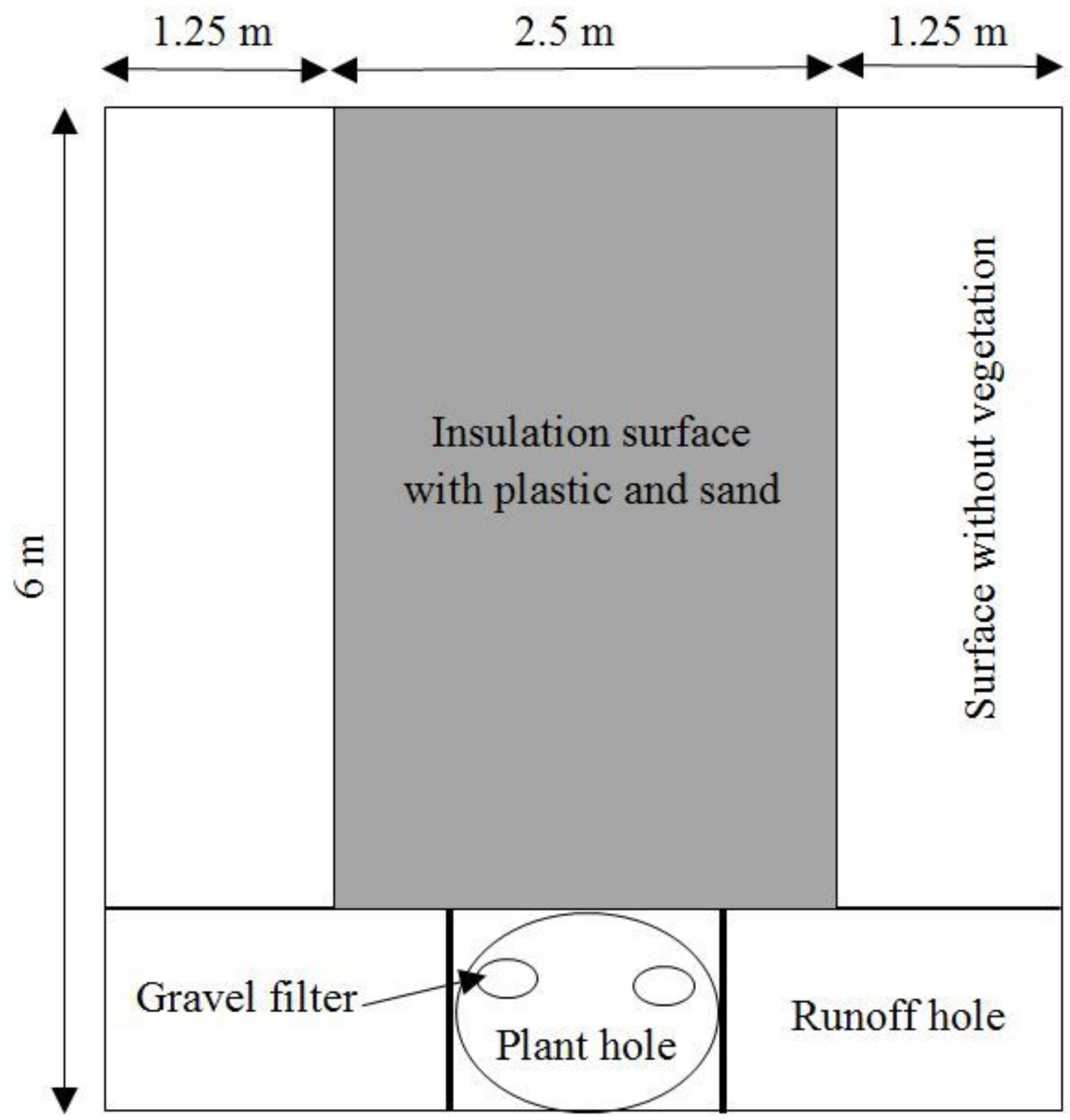

Figure 4

A shematic of semi-isolated plots with plastic and sand cover

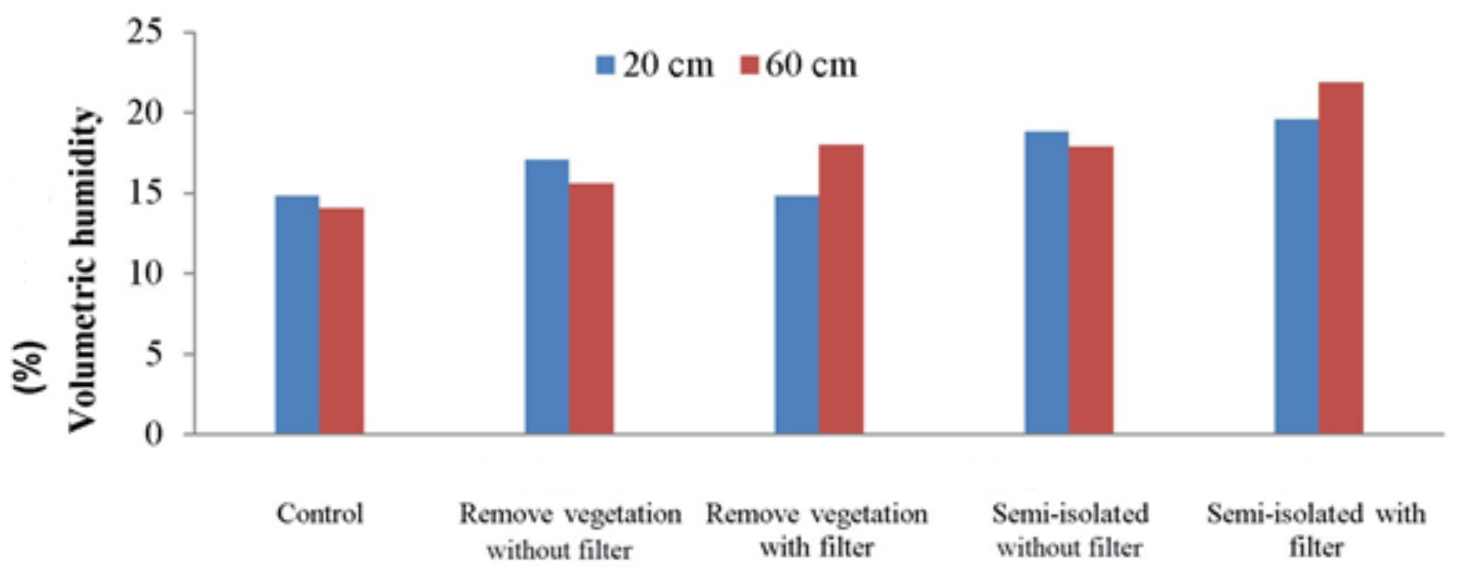


Figure 5

Comparison chart of soil moisture content in different systems at 20 and $60 \mathrm{~cm}$ depth 